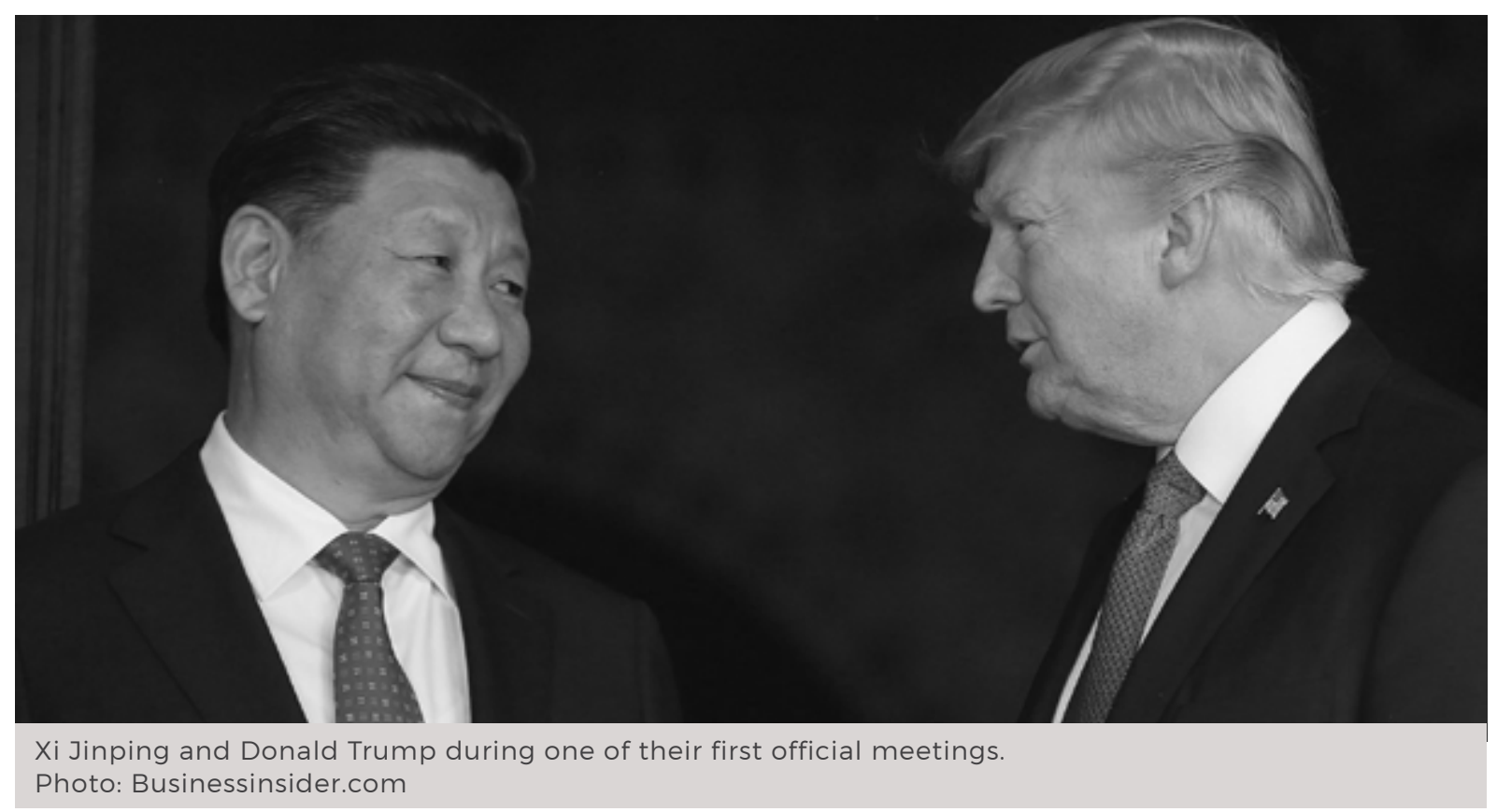

\section{Prospects for US-China Union Relations in the Era of Xi and Trump}

\section{Katie Quan}

Under the presidency of Xi Jinping and Donald Trump, relations between trade unions in the United States and China have come to a virtual standstill. To understand how we arrived at this point, and what can be done to break the impasse, this essay briefly reviews the historical development of union relations between the two countries. In order to achieve this, it draws on voices of those labour leaders in the United States who have been direct participants in efforts to develop early contacts with their Chinese counterparts.
In October 2013, Richard Trumka, President of the American Federation of Labour and Congress of Industrial Organisations (AFLCIO), visited the All-China Federation of Trade Unions (ACFTU) to establish formal bilateral relations between unions in China and the United States. This visit signalled an historic shift in labour policy, from Cold Warstyle hostility to normalisation of relations. Some American labour activists hoped that it might further lead to collaboration on joint activities, such as collective bargaining. That collaboration would be a significant step forward in labour solidarity and building a global labour movement.

However since then progress towards building relations has been decidedly slow. There have been only a couple of official exchanges with the AFL-CIO, and activities sponsored by Change To Win (CTW), the splinter group of the AFL-CIO that first began relations with the ACFTU a decade ago, have decreased. Some American labour leaders have noted that the ACFTU has become less interested in collective bargaining since $\mathrm{Xi}$ Jinping's campaign against corruption began. Now, given Donald Trump's election as US President with his agenda to weaken the 
American labour movement and start a trade war with China, it is fair to ask whether there are any prospects for progress in relations between unions in China and the US, and if so where.

To understand the American perspective on the relationship between the US and Chinese unions, I will briefly review the historical development of relations between workers in the two countries. Then, I will address more recent union relations based on information obtained through semi-structured interviews with a dozen labour leaders in the US who have been direct participants in efforts to develop those relations. Finally, I will discuss the challenges and opportunities laid out by my informants and draw conclusions.

\section{A Troubled History}

The root of American attitudes towards Chinese labour have been shaped by race, class, and ideology. Since the nineteenth century there have been xenophobic fears of the 'Yellow Peril' represented by Chinese workers, as well as arguments that workers of European ancestry should cast their lot with American business and shut out Chinese workers. These fears were compounded in 1949, when China became a communist state and an ideological enemy, resulting in antipathies that linger to this day.

After World War II, the Cold War set in, and the world was divided into two main ideological camps: the communist and the 'free world'. In 1949, American unions led a split in the World Federation of Trade Unions (WFTU) - a global union that aspired to bring together unions from all over the world into a single organisation-to form the International Confederation of Free Trade Unions (ICFTU), an alliance of free world unions. Meanwhile, the WFTU came to be known as the federation of communist unions, to which the ACFTU was affiliated. Back then, divisions in the international working class mirrored ideological debates among nation-states. The ICFTU consistently criticised the ACFTU for not being a free and independent trade union, and therefore declared that it was not an 'authentic' voice of Chinese workers.

However, in 1979, when China opened its doors to foreign investment and diplomatic relations with the US were established, the material basis for this divide changed. Multinational corporations raced to China to take advantage of the low-cost labour. Factory conditions were appalling and workers were exploited, causing outcry among international consumer and human rights activists, and drawing criticism of the Chinese government and its unions for not protecting workers. At a time when international labour solidarity might have meant American workers reaching out to workers in China, American unions continued to refuse to have anything to do with Chinese unions, repeating the Cold War rhetoric that they were neither independent nor authentic. Meanwhile, some left-leaning labour organisers worked quietly in the background to coordinate worker-to-worker exchanges between US and Chinese workers, hoping to build solidarity.

The Tiananmen Incident in 1989 proved to be a setback for these budding relations. The crackdown on the protests was viewed worldwide on cable news in real time, and its brutality reinforced what many American labour unionists had believed all alongthat despite capitalist markets and openness to meeting foreigners, China was still an authoritarian state that did not respect human rights. The AFL-CIO response was to support a few Chinese labour activists in exile, and to continue to boycott relations with Chinese unions.

At that time, American unions supported campaigns targeting international brands, pressuring these companies to accept corporate social responsibility in their supply chains. The theory was that the brands had power to control labour conditions in 
factories that manufactured their products. In Latin America, Africa, and Southeast Asia, these cross-border campaigns, mostly led not by unions but by non-governmental organisations (NGOs), had modest success in supporting worker organising. However, with respect to China-where an increasing share of the world's export manufacturing was taking place, and where supply chain organising strategies might have had an impact on the global economy-no NGO ever figured out how to get brands to pressure the Chinese government to allow workers to organise themselves.

Another response of American unions was to push for trade sanctions against China. Arguing that the low labour standards in China undercut American jobs, the AFLCIO sought to block China from entering the World Trade Organisation (WTO) and from receiving Most Favoured Nations status under Permanent Normal Trade Relations (PNTR) with the US. Using the race card once again, the AFL-CIO's petition against PNTR painted a dehumanised picture of Chinese workers as willing slaves who were willing to work for practically nothing, thus undermining the standards of American workers. It argued that sanctions would force the Chinese government to improve conditions for Chinese workers. So at the turn of the twenty-first century, racist stereotypes of Chinese workers that were common over a century before were still being used, and policies from the Cold War era that ended nearly half a century before still kept Chinese and US workers divided.

\section{First Engagements}

Meanwhile, global labour activists continued to organise worker-to-worker exchanges. In 2002, Andy Stern, president of the Service Employees International Union (SEIU), participated in an exchange that was facilitated by Kent Wong for the Asian
Pacific American Labour Alliance (APALA), a constituency group of the AFL-CIO that was formed in part to break through racial stereotypes of Asian workers. Stern was later criticised by AFL-CIO leaders for having visited China, but he was firmly convinced that China was important to the global economy, and he was determined to develop relationships with the ACFTU. Importantly, he was an activist union leader, so he was looking not just to have fraternal affiliations, but also to find ways to collaborate on joint action. One of the issues that SEIU continuously raised with the ACFTU was its concern about Walmart. In 2005, SEIU was heavily involved in the American labour campaign against Walmart, and Stern hoped that there was a way for US and Chinese unions to collaborate.

In 2005, when SEIU and other unions broke away from the AFL-CIO to form the CTW federation, Andy Stern persuaded other CTW leaders to go to China to see things for themselves and to propose joint action. One of these leaders was James Hoffa, president of the Teamsters union, and an active opponent of PNTR for China. Staffed by veteran international labour activist Tim Beaty, Hoffa's approach to relations with Chinese unions was open but cautious. As Beaty told me in an interview in February 2017:

I did have an idea that by going to China, talking directly to folks, even in formal contexts, about leadership elections, how we collectively bargain, that maybe there would be an opportunity to see an alternative way. We might get discussion, contribute to the process of change inside the ACFTU, and create a different consciousness, broaden alternatives and possible reforms. Maybe this would legitimise people who had more democratic idea of getting workers involved. I have no idea that that has happened. Maybe I was naïve.

Another CTW leader who travelled 
to China, United Food and Commercial Workers (UFCW) President Joe Hansen, was interested in the connections that Chinese unions had with the same employers. Early on he was concerned about the impact of Chinese companies selling pork to the US, and later in 2013, he became concerned when the Chinese company Shuanghui International purchased Smithfield Food, an American meat processor where the union had won an organising campaign after a long and bitter battle. Shuanghui, now known as WH Group, recognised the union, added 38,000 workers to the payroll, and has continued the collective bargaining relationship.

In other words, from the early 2000s, CTW unions stepped into uncharted territories to try to get to know the ACFTU and find out what kind of relationship and joint action was possible. The Teamsters hoped that engagement would lead to labour solidarity as they practice it with other countries, but repeatedly found that the ACFTU side was not interested in providing information or writing letters of solidarity. UFCW also hoped that there could be joint work with the ACFTU on mutual employers, but found little interest at the regional level, though a proposal for a research survey sent ripples that were felt worldwide. SEIU built deep relationships that made important headway in the Walmart campaign, but found that unionising China's Walmart workers did not actually provide workers with a voice. These unions found that their concepts of solidarity might be very different from those of the ACFTU, and that their goals for developing relationships and activities might not be exactly the same.

\section{AFL-CIO and China}

In 2011, the ACFTU made a bid for a seat on the governing body of the International Labour Organisation (ILO), which placed the AFLCIO in the middle of an international debate. Many American and international unions opposed the bid on the grounds of the old ICFTU arguments that it was not independent and not authentically representatives of Chinese workers. On the other hand, other labour movements supported the bid, on the grounds that the ACFTU is the official union of China and it represents the largest working class in the world. In this path-breaking vote, the AFL-CIO abstained, paving the way for the ascendance of ACFTU to the ILO governing body.

The AFL-CIO decision was advanced by its International Affairs Director, Cathy Feingold, who in an interview I had with her in January 2017 rationalised: 'We thought constructive engagement was important, but we could not fully endorse, because of human rights and other issues.' In the end, the decision paved the way for Feingold to begin a process of building relationships with ACFTU leaders at the ILO, and making plans for AFLCIO President Richard Trumka to visit China. Her efforts bore fruit in September 2013, when Trumka and a small group of AFL-CIO staff made the first official AFL-CIO visit to China. Though this visit was relatively lowkey, it was nevertheless historic, given the hostile relations that had existed between US and Chinese workers in the previous decades.

In spite of the goodwill expressed during Trumka's visit, progress in building relationships between Chinese and American unions has been slow, for both AFL-CIO and CTW unions. Both federations say that exchanges are cordial, though veteran China labour hands like Josie Mooney and Kent Wong in interviews I had with them in January and February 2017 say that frank conversations are more difficult since there have been many changes in union leadership in both countries, and trust relationships have to be rebuilt. According to my interviewees, in recent years there have been some tensions, like with the Chinese government's 2014 criticism of the AFL-CIO's decades-long support for the Hong Kong Confederation of Trade Unions, through its international education arm, the 
American Center for International Labour Solidarity. The ACFTU has also voiced displeasure with the City University of New York's grant from the US State Department to do labour education in China.

One new development involves union relations at Chinese firms investing in the US. In 2016, Chinese companies invested nearly 54 billion USD in the US in various industries, which was up 359 percent from the previous year. There is no systematic data on how these investments are affecting labour relations, but there are at least some cases, like the Smithfield Foods case mentioned earlier, which appear to indicate that Chinese employers are not necessarily anti-union. In such a context, once again attempts have been made to build relationships between Chinese and American unions vis-a-vis a common employer. Instead of building the relationships by building union-to-union ties, this strategy relies on the employer as the bridge between the unions, at least initially.

\section{The Larger Picture}

Relations between unions in the US and China are one aspect of the larger picture of global capital and global labour. Presumably, if the labour movements in the US and China were strong, and relations between the two countries were strong, they could muster a countervailing force against multinational capital. Towards this end, some American unions have attempted to establish relations with unions in China to work on joint campaigns against common employers. While in the process they have broken through some stereotypes and misconceptions about China and Chinese workers, in general they have found the ACFTU to be welcoming and cordial, but perhaps not so interested in joint campaigns against common employers aimed at worker empowerment. In spite of this, American unions remain committed to searching for ways to work with Chinese unions.

Under the current presidencies of $\mathrm{Xi}$ Jinping and Donald Trump, it is possible that these fledgling attempts at building relationships will be further set back. Under $\mathrm{Xi}$, the Chinese government has cracked down on human rights and labour activists, and has put NGOs under the administration of the Public Security Bureau, its domestic security agency. This may make the ACFTU less interested in sharing information with American unions about activating workers, particularly with regard to coordinating collective bargaining and strategic campaigns. Meanwhile, Trump's current agenda includes a myriad of threats to lower labour standards, eliminate collective bargaining rights, and substantially weaken union influence. American unions are currently preparing for major defensive battles, and have already announced substantial staff layoffs and financial cutbacks. Given these challenges to their survival, they may have little resources left for international solidarity.

One area that might have complex consequences is international trade. Donald Trump has already announced that the US will withdraw from the Trans-Pacific Partnership (TPP), decrease its role in the World Trade Organisation, and hold China accountable for currency manipulation. He has even hired Peter Navarro-producer of the fervently anti-China film Death by China- as his chief trade adviser and many observers are concerned that they intend to start a trade war with China. Some US unions, like the autoworkers and steelworkers, are cheering Trump's positions on trade (even as they face decimation from Trump's domestic labour policies), because they believe that trade barriers will bring back jobs to American workers. It is hard to say at this point if trade barriers will cause American firms to reinvest in the US, without knowing what the specific policies and comparative costs will be. In any case, it will be important to watch out for racial stereotyping that has been used to 
advance support for protectionist trade in the past.

Meanwhile, Xi Jinping has stepped into the vacuum left by Trump's retreat from global trade, and is proposing that China lead the world's new economic order. Among many concerns, this raises the question as to whether China would consent to a labour clause as a core chapter in these international trade agreements, something that global labour activists have spent many years fighting for, and have actually achieved in cases like the TPP. These labour clauses have varied in effectiveness, but in some cases they have provided the basis for workers to advance rights, like freedom of association in Vietnam. Given China's poor record on labour standards enforcement domestically, it would be a surprise if it agreed to a labour clause in international trade agreements. Of course, the ACFTU would be bound to support Xi's position because it is subordinate to the Chinese Communist Party, but this position would also be consistent with views that were expressed to American trade unionists on numerous exchange visits.

In an era when relations between unions in the US and China do not progress or even regress, what is to be done? According to veteran labour activist Apo Leong, whom I interviewed in January 2017, 'Over the years we've seen political windows open and close, and during the closed periods labour organisers need to continue foundational work that will put them in a better position to advance when the political window opens.' For American and Chinese unions, this might mean that both sides should continue to have official exchanges, while understanding that the pace of engagement may not accelerate. It also suggests the need to evaluate where some gains can be made, perhaps in areas of mutual interest other than strategic campaigns, like health and safety or labour law. Aside from high level official exchanges, US and Chinese unions might also consider increasing lower level dialogues among union members and staff aimed at strengthening friendshipsuch as member-to-member visits, staff internship exchanges, and technical and research exchange. After all, US-China union relationships will continue to be critical to labour power in the global economy, but given the current political climate, organisers need to be more strategic than before and ensure that the one step forward is not undone by two steps backwards.

\section{Katie Quan}

Katie Quan is a senior labour specialist at the UC Berkeley Center for Labour Research and Education. She specialises in labour in the global economy, and was formerly Co-Director of the International Center for Joint Labour Research at Sun Yat-sen University, Guangzhou. Prior to working in academia, Katie Quan was a seamstress, organiser, and officer with the garment workers' union in the US. 